\title{
Sugar for the tea: assistance and the state of pastoralism in the Horn of Africa
}

\author{
Gilles Stockton*
}

\author{
Correspondence: gillesstockton@ \\ gmail.com \\ Stockton Ranch, P.O.Box 182, Grass \\ Range, MT 590322, USA
}

\begin{abstract}
This short note discusses some of the realities faced by the 20 million pastoralists and the international agencies that deliver emergency and development assistance in the pastoral arc of the Horn of Africa (HOA). Isolation, poor roads, spotty telecommunications, and insecurity make it difficult for donor agencies and nongovernmental organizations (NGOs) to implement projects. In the donor countries, short-term and shifting funding priorities for emergency and development assistance make long-term planning by donor agencies and NGOs difficult. This all conspires to create a system that delivers 'things' but does not deliver economic security to pastoral communities. Water development, provided through the programs that also deliver emergency food rations, tends to promote the growth of villages in previously uninhabited pastoral grazing areas. The village's resident population of livestock causes environmental degradation and constrains the mobility required for successful and sustainable pastoralism to function. The pastoral areas of Kenya are beginning to be economically and politically integrated with the rest of Kenya. However, the pastoral communities of Ethiopia continue to be estranged from the central government of Ethiopia. In northern Somalia, investments by Somali businessmen, remittances from the diaspora, and international assistance have resulted in a relatively stable economic and political system. In southern Somalia, because of continued conflict, about three million people are dependent upon food and emergency assistance. When peace is finally negotiated in the HOA and true development assistance becomes possible, there will be a population that is too large for the deteriorated environmental base, and too few economic opportunities for too many people who are underprepared to meet that future.
\end{abstract}

Keywords: Development policy, Somalia, Somaliland, Kenya, Ethiopia, Horn of Africa

\section{Springer}

\section{Background}

When a young man asked me what I was there to give them, I responded with a curt 'nothing'. I was irritated by his question, but upon reflection, it was fair. After all, this is the way the humanitarian and development assistance systems deal with his people in his little village lost somewhere between Mandera and Moyale in northern Kenya. Someone shows up one day to give them something. Perhaps, it is a water pan, or maybe a school, and most probably some relief food. After an appropriate discussion with the village elders, the agreed-upon assistance is delivered and the aid workers go away, only to reappear sometime in the future to give them something else. Every village in the pastoral areas of Kenya, Ethiopia, Djibouti, and Somalia has a collection of 
sign boards announcing that 'such and such' "assistance was provided by 'this' nongovernmental organization (NGO) or 'that' and funded by USAID, EC, DIFD, UNDP or the World Bank (see Figures 1, 2 and 3).”

This is how 'we' provide humanitarian and development assistance to pastoral peoples in the Horn of Africa (HOA). There are good reasons that explain why: it is expensive to maintain a permanent office and staff in these remote areas; communication between these villages and headquarters in Nairobi or Addis Ababa is tenuous at best; security, or rather insecurity, is a constant worry; and funding by the donors to the NGO implementers is short-term and haphazard. This all conspires to create a system that delivers 'things' but does not deliver economic security.

Foreign assistance comes in two basic forms: humanitarian assistance, which is shortterm ( 1 year) and aimed at saving lives and reducing suffering during an emergency; and development assistance, which is longer-term ( 2 to 5 years) and directed at improving the economic security of the target population. The two forms of foreign assistance are commonly administered by different agencies with funding sources that come from different pools in the donor country. The amount of humanitarian assistance, primarily food staples, exceeds the amount of development assistance in part because the HOA is considered a place in permanent crisis. For instance, in 2008, USAID spent US \$295 million for humanitarian assistance in Somalia versus 26 million in development assistance.

\section{0 million people, 3 million on the move}

There are about 20 million people living in the pastoral arc of the Horn of Africa - the largest conglomeration of pastoralists in the world. This arc stretches from the territories of the Afar where Eritrea, Ethiopia, and Djibouti meet and passes down through Somalia and eastern Ethiopia (Ogaden), and west across northern Kenya to the territories of the Turkana and Pokot. About half of these pastoral peoples belong to clans associated (sometimes loosely) to the Somali identity. The Oromo are the next largest tribal group.

All of these pastoralists share a culture of living from sheep, goats, cattle, and/or camels which graze on arid and semi-arid pastures. The key for these nomadic peoples is mobility because rainfall is erratic; the herds must travel long distances for feed and water. Clan survival also depends upon two contradictory principles. The clan elders are tasked with negotiating and mediating a network of reciprocal agreements with neighbouring people which gives the clan access to water points and pastures during drought or conflict-related emergencies. But clan survival also depends upon the ability to defend the clan's resources and the willingness to take water points and pastures by force if the situation requires or if the neighbouring people cannot defend themselves. Consequently, the pastoral arc has historically been an area of continual conflict, a reality that is increasing as populations increase and natural resources are over-exploited.

Humanitarian food assistance is obviously most needed in the southern parts of Somalia where up to three million people are on the move attempting to avoid the conflict. Although there have been many valiant attempts on the part of the NGO implementers to maintain permanent presences with the communities with whom they are engaged in southern Somalia, open conflict eventually engulfed most areas, and the NGOs have been forced to evacuate. I believe that currently, no NGO international staff can visit their project sites and just recently, the United Nations has suspended operations in much of southern Somalia. In fact, for the last number of years, the NGO 


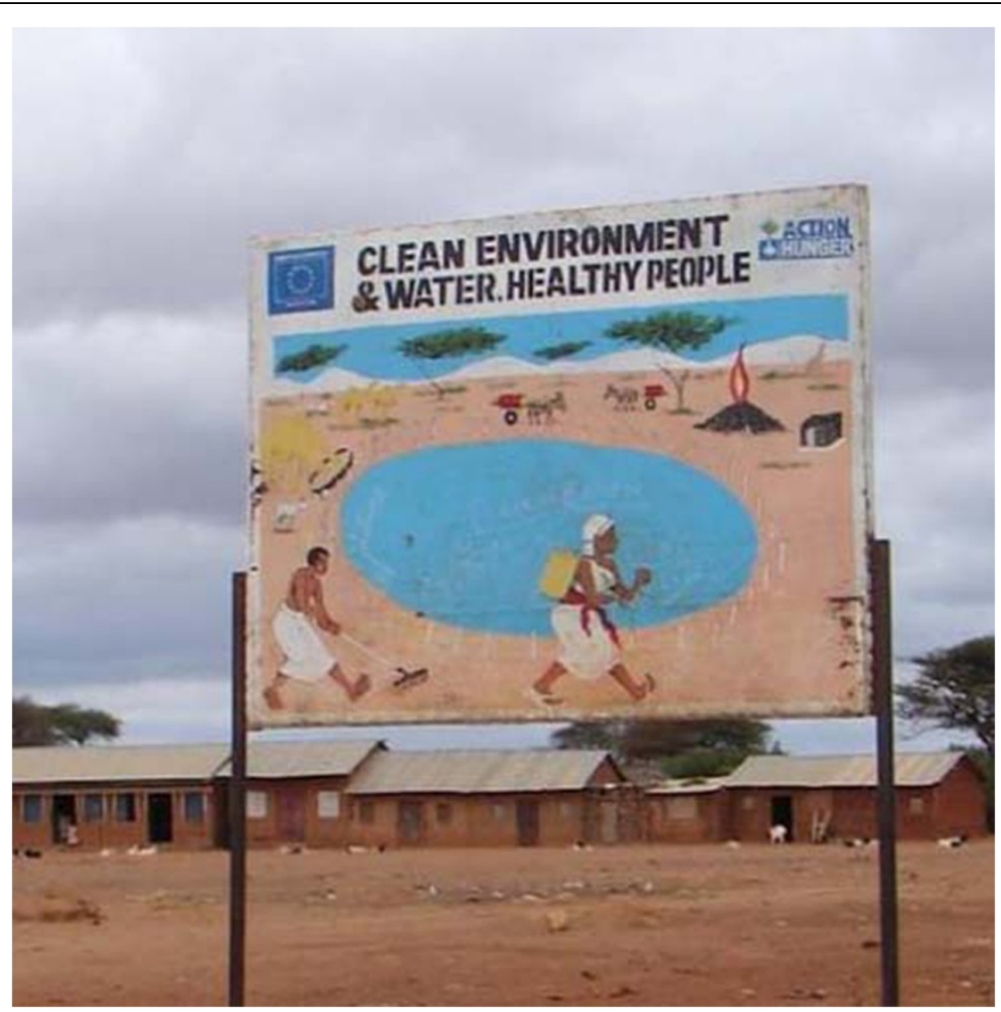

Figure 1 Sign for donor-sponsored project in pastoral Ethiopia (1).

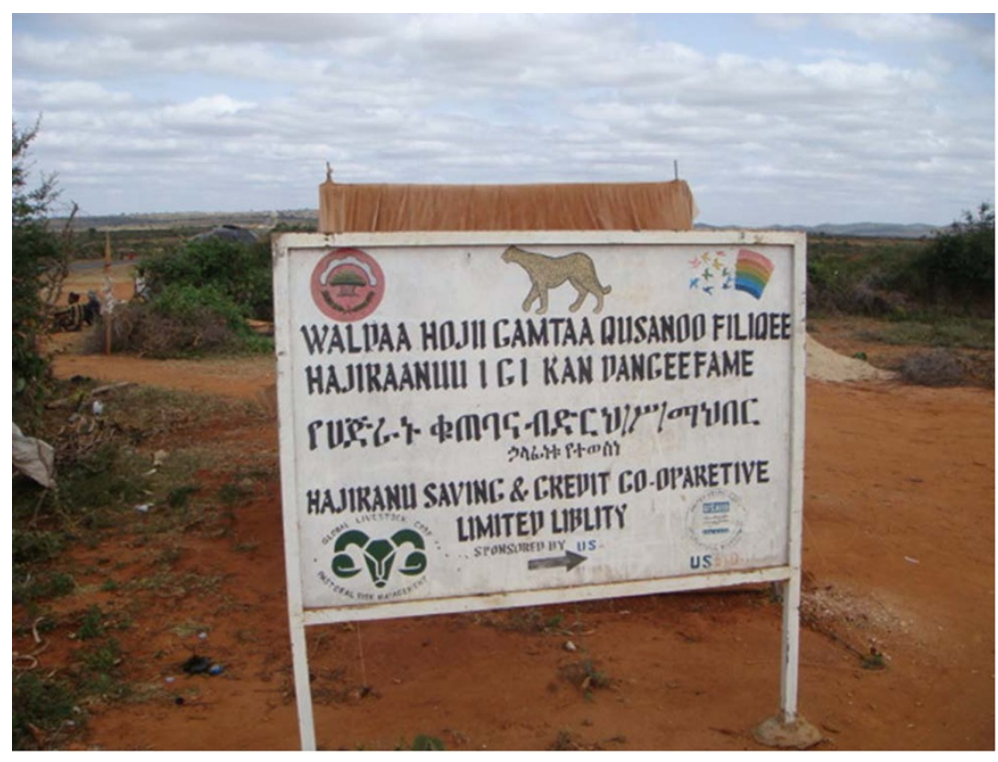

Figure 2 Sign for donor-sponsored project in pastoral Ethiopia (2). 


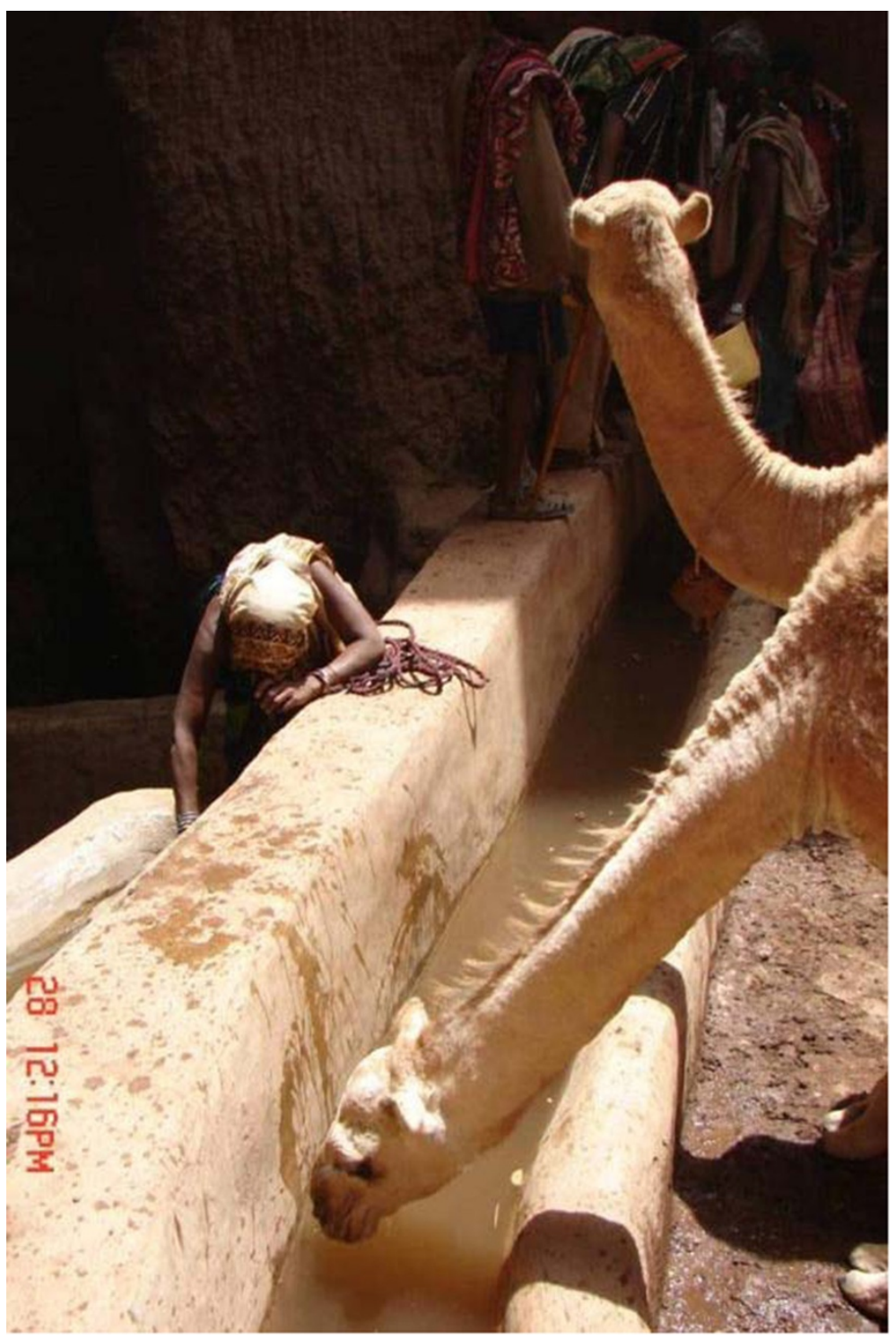

Figure 3 Camels drinking from rehabilitated water trough.

presence in southern Somalia has been staffed primarily by Somali and Kenyan citizens. This staff does heroic work in a chaotic and dangerous environment, but their work has been limited as to what they can actually accomplish.

\section{Pastoral Kenya and Ethiopia have different realties from Somalia}

Northeast Kenya and the Somali National Region of Ethiopia have different realities from Somalia. The conflicts in those areas are more directly related to control of pasture and water although it should be noted that at its core, the conflict in southern Somalia is also related to the control of pasture, water, and other economic resources including the anticipated foreign aid. Historically, the governments of Kenya and Ethiopia have neglected the economic development of pastoral regions, from their point of view, for good reason. The northern and northeastern lowlands of Kenya were 
considered by the post-colonial government of Kenya to be a source of insecurity and banditry with little economic potential. In the eyes of many, Kenya stopped, or started (depending upon the direction you were looking), at Isiolo and the Tana River. Kenyans of a certain age still recall the Shifta War with disdain for the Somali protagonists. The result is that these territories have little in economic infrastructure: not many kilometres of all weather roads, spotty access to telecommunications, few banks, and, outside larger towns, no schools. That neglect is changing as the politics of Kenya matures. Politicians from the pastoralist communities now hold the balance of power in the Kenyan parliament, and as a consequence, development funds are flowing to the lowlands. However, they have a long way to go before the pastoralist areas have the infrastructure needed for a sustainable environmental and economic system. But this new focus on the pastoral populations brings its own problems because much of the assistance can be inappropriate, an issue that I will discuss in the succeeding paragraphs.

The situation in the pastoral areas of Ethiopia, particularly the Somali National Regional State (Ogaden), is very different. Unlike the Kenyan Somali population, who now see advantage in being Kenyan citizens, Ethiopian Somalis do not seem to share that same attitude towards Ethiopia. Even though the federal system that now constitutes the government of Ethiopia gives each Regional State much political autonomy, people do not appear satisfied and insurgency simmers. Consequently, the highlanders who control the government in Addis Ababa and who are already nervous about the chaos in Somalia see the conflicts in the Somali National Regional State as a destabilizing threat. The result is military repression of the occupants of the Ogaden, little different from that historically experienced under the Ethiopian emperors. The Ethiopian army chases down and confiscates herds from nomads whom they suspect of smuggling livestock out of Ethiopia. The nomads, who of course do not consider taking their livestock to Somaliland or Kenya as smuggling, fiercely resent the interference. Somali businessmen who smuggle consumer goods into Ethiopia without bothering to pay taxes - goods often purchased with the proceeds from the exports of livestock often originating in Ethiopia - just fuel the Ethiopian government's resolve to impose order and control on the Somali regions.

Given the Ethiopian government's negative perception of their pastoral citizens, very little infrastructure development is offered to those regions. It should be noted that Somalis are not the only tribal group that is disadvantaged, because the Ethiopian government also has problems with the Afars to the north and the Oromos to the south. One modern technology with the potential to be transformative to pastoral people is the mobile phone, but the Ethiopian government keeps a tight rein on the communication system. NGOs working in the pastoral areas are viewed with considerable suspicion and must be careful so that their staff members are not arrested and their programmes suspended. Food aid is controlled by the government, and truck convoys carrying food are sometimes blocked from going to people that might be supporting insurgents. From the Ethiopian government's point of view, all of these disadvantages to the pastoral areas are rational and part of their mandate to keep control of their country.

\section{The mobile phone: transformative technology}

I mentioned above that the mobile phone is a transformative technology for pastoral people. They certainly see it that way; in Kenya and Somalia, every nomad who can has 
a mobile phone. This makes sense from two different cultural aspects of pastoral people. First, they are oral societies with low literacy levels. The mobile phone is the perfect tool for people who communicate with each other by talking. Second, mobility is the key to survival for nomadic people. Adaptation to modern realities requires that pastoral families spread their human resources to other enterprises than herding livestock - in essence, expanding the range of their nomadic activities. Pastoral family survival in modern times requires that family members have businesses or jobs in other areas - even in other countries. But if they are to remain a family, they need to stay in communication with each other. The mobile phone is the perfect technology. This is why the telecommunications system expanded so quickly in the economic free-for-all of post1991 Somalia. In Kenya, after the government monopoly on telecommunications was subject to private enterprise competition, the mobile network also expanded rapidly. The mobile phone companies have been surprised to find that many of their most profitable cells are in the sparsely populated pastoral areas of northeastern (NE) Kenya.

The NE region of Kenya now gets $52 \%$ of food needs through the humanitarian food system. The food aid initially comes as a response to drought emergencies but never stops because of pressure by Kenyan politicians. There is no question that there is a livelihood crisis in the pastoral areas. If you consider numbers of livestock, for instance in Mandera District of Kenya, you will find that there are only enough animals to provide a minimal living for $40 \%$ of the human population. As you travel through NE Kenya, you pass little clusters of dilapidated nomadic huts (aqals), put together with pieces of cardboard, plastic, and empty maize sacks. If a food distribution is imminent, these camps are occupied; otherwise, they are abandoned.

\section{Targeting, fraud, strategy, and conflict}

The targeting of food aid to recipients that have the most needs is difficult. Usually, the clan elders are asked to identify persons who require food assistance. The elders naturally try to include everyone in the clan. After all, it is free food. Many recipients, of course, need the food aid to survive, but others sell the food. It is expensive to deliver the food because so much of it is diverted at every stage of the process, and the long distance it is transported over sometimes nearly impassible roads is costly. So you have the absurdity of some of the food aid recipients selling the food for a fraction of the cost of delivery. Food aid is a very inefficient way to deliver assistance to people, particularly now when neither the USA nor Europe has surplus supplies of maize or wheat. In the NE part of Kenya, there is an experiment in progress to provide the poorest of the poor with cash instead of food. On the surface, this approach makes sense as it is more efficient. But the problems of targeting and fraud continue. And, too, there is something fundamentally wrong in creating a dependency on outside assistance without making a sincere effort to give these people the tools to live independent productive lives. And it is wrong to make people dependent upon outside assistance when there is no guarantee that the assistance will continue.

Another thing happening because of food distribution is that the food relief camps tend to turn into small villages, especially, when permanent water sources are developed. Water is the key to all of it. Ask any pastoralist what it is that he needs most and he will reply 'water'. This fits well into the work of the humanitarian and development 
systems because water development is relatively easy and inexpensive to support. The only problem is that water development is destroying the environment and accelerating the cycle of drought emergencies. This is because the inhabitants of each village keep a resident herd of livestock which utilizes the pasture within a day's walk around the village. With more villages springing up, more and more areas are depleted of grass or browse, reducing the mobility of the nomadic herding system.

Survival for pastoralists, as I wrote above, depends upon mobility because the rainfall pattern in the Horn is erratic. The herds must follow where the rain has fallen. What pastoral groups developed over the centuries are large ranges that increased the probability that it would rain somewhere within their territory. Much of that range had no permanent water source and could only be used during the rainy season. This left wide areas within the nomadic system with plentiful grass, browse, and wildlife. The nomads would trek their herds to these places in the rainy season and return to their core pastures where they had permanent water and where grazing had been prohibited by mutual consent to be used only in the dry season.

The proliferation of villages with permanent water sources in what had been dry season grazing areas is disrupting the entire nomadic system. Not only is this accelerating environmental deterioration and increasing the frequency of drought emergencies, but it is also creating tribal conflict. Currently in northern Kenya and southern Ethiopia, there are armed conflicts between the Garre and the Marehan across the border of Kenya and Somalia, between the Garre and the Borana in southern Ethiopia, between the Borana and the Gabra across the Ethiopia - Kenya border, and between the Pokot and the Turkana in western Kenya. These are all conflicts over control of the grazing and water.

\section{Borana territory: the sugar for the tea}

In my travels and work in the HOA, I have come across a few pastoral visionaries. These are men and women, pastoralists themselves, who believe that pastoralists must take control of their own destinies. If assistance from the outside is to help more than it hurts, that assistance must be guided by the recipient community itself.

This is easier said than done. I have discussed with Somali friends and read other accounts written by Somalis who despair that their clan system is totally dysfunctional in dealing with the forces that have engulfed Somalia. I am not convinced. The one thing that Somalis and other pastoralists have is community, and belonging to, and having a place within that community. The issue is how to use that clan-based community to solve the problems faced by the community rather than let the community disintegrate and follow the leadership of the most greedy and violent among them. The cultural tools are there, already in place, for the communities with the will to use them to solve their common problems. Winner-take-all brute force does not have to prevail.

It is a small story, but it is perhaps indicative as to how the international assistance system and national governments can work with community leaders to guide pastoral communities to confront the difficult issues they are facing. In 2008, I travelled into northern Kenya and southern Ethiopia to look at projects funded by USAID. In southern Ethiopia, there is an area referred to as the Singing Wells. These are amazing wells dug over the centuries by the Borana people of the region. After a certain depth, it is impractical to raise water by hand all the way to the surface, so the people have dug 
trails into the earth to a staging area where the water troughs can be filled by a chain of five or six men perched on ledges in the wells themselves. The staging area is 15 to $25 \mathrm{~m}$ below the surface of the earth, and the water itself is another 10 to $15 \mathrm{~m}$ farther down the well. The men of the clan pass the containers of water up one to another to fill the watering troughs for the herds, singing to coordinate this hard work in the depth of the cool earth.

I visited these wells with a young Borana man who was working for an international NGO involved with his community. He showed me a well where the NGO had provided funds to expand the opening and the trail into the well and to make a permanent concrete trough where before the people had mud troughs that needed continual repair. It was impressive and certainly useful, but I asked the young man why they had provided funds to do this. He said that it was a model for other clan groups who have similar wells. However, upon further questioning, it came out that there were eight wells in the immediate vicinity and the NGO had provided funds to rehabilitate five of them, presumably with plans to rehabilitate the remaining three. I did not argue with this young man, but I failed to understand how, if the NGO was rehabilitating all of the wells, this could be considered a 'model'.

Later on that trip, I visited an area in northern Kenya, also Borana territory, and was assisted by a local NGO. Again, I visited wells that had been improved by the addition of permanent concrete water troughs. I asked the Borana man who ran this NGO why he had elected to do well rehabilitation. He said that he was 'bringing sugar for the tea'. His point was that everybody has tea but sugar is expensive and if you are going to have a meeting, someone has to provide the sugar for the tea. The concrete trough was the 'sugar' to give him a forum to discuss the broader issues faced by that community of pastoralists.

\section{On the one hand, and on the other}

Is this too idealistic? Is it possible for the foreign assistance industry to collaborate with pastoral communities and together guide economic development? The distance between the world capitals where decisions to fund foreign assistance are made and a small village in the Mandera Triangle which receives those funds is much more than just the air miles between. Washington and Brussels live in a reality based on the political winds of the United States and the European Union. Pastoralists of the Horn are, you might say, stretched between the realities of the present and the traditions of the centuries. For nomads in the Horn, the tension must be extreme because the past is not yet over and the present has not quite arrived.

The human population of the pastoral areas of the Horn is too large for what the environment is able to provide. But too many of the people are under prepared to lead lives other than as pastoralists. Their social and clan governance systems are seemingly unable to cope with the changing conditions and circumstances imposed by the outside world. And their national governments along with the international humanitarian and development systems too often respond with assistance that increases the problems.

I am overstating this to some degree because, for the inhabitants of northern Somalia, conditions are not that bad. In fact, it seems to me that northern Somalis have a better 
economy now than at any time in the 40 years when I have witnessed conditions in Somalia. In Kenya, things are changing for the better. The city of Garissa in eastern Kenya is booming, as is the Somali enclave of Eastleigh in Nairobi. Also, of the million Somalis now resident in the Middle East, Europe, and North America, many are helping financially the people still in the homeland.

But on the negative side, conflict reigns in southern Somalia, and that conflict has now taken on religious overtones where before it was primarily economic. We cannot expect too much progress until peace returns over the whole of the Horn of Africa, and peace now seems further away than ever. But when that day arrives, we will still be left with a population that is too large, an environment which is deteriorating, and too few economic opportunities for too many people who are underprepared to meet that future.

\section{Competing interests}

The author declares that he has no competing interests.

Received: 26 January 2012 Accepted: 17 May 2012

Published: 17 May 2012

\section{References}

Akiliu, Y. 2006. Camel marketing and pastoral livelihoods in Ethiopia. Feinstein International Center: Tufts University. Akilu, Y. 2009. Livestock exports from the Horn of Africa: an analysis of benefits by pastoralist wealth group and policy implications. Feinstein International Center: Tufts University.

Bishop S.2008. Issues Emerging from the IGAD LPI National Stakeholder Consultative Fora: Djibouti, Ethiopia, Kenya, Sudan and Uganda.2008

Desta, S., G. Gebru, S. Tezera, and D.L. Coppock. 2005. Linking pastoralists and exporters in a livestock marketing chain: recent experiences from Ethiopia. Utah State University Pastoral Risk Management Project: Research Brief 05-06 PARIMA.

Devereux, S., April 2006. Vulnerable livelihoods in Somali Region Ethiopia: IDS Research Report 57. Institute of Development Studies.

FAO/IGAD. Pro Poor Livestock Policy Initiative, PPLPI working paper no 37 entitled: "Policies and strategies to address the vulnerability of pastoralists in Sub-Saharan Africa"

Fassil Kebebew, Diress Tsegaye, Gry Synnevag. 2001. Traditional coping strategies of the Afar and Borana pastoralists in response to drought. DCG Report No. 17,

Food Security Analysis Unit - Somalia (FSAU). 2006. Integrated food security and humanitarian phase classification: technical manual. version I, 56. Nairobi, Kenya: Technical Series Report No. IV. 11.

ILRI. 2006. Pastoralism and Poverty Reduction in East Africa: A Policy Research Conference. 27-28 June 2006. Nairobi, Kenya. ILRI supported by the World Bank Arid Lands Resource Management Project, USAID Strategies and Analysis for Growth and Access (SAGA) cooperative agreement, directed by Cornell University and co-directed in Kenya by the Institute for Policy Analysis and Research, and by the USAID Global Livestock CRSP Pastoral Risk Management (PARIMA) project, led by Utah State University.

LEGS Steering Group. 2006. Livestock Emergency Guidelines and Standards: Livelihoods-based Livestock Interventions in Disasters

International Crisis Group. 2006. Can the Somali Crisis be contained? Africa Report N¹16, August 2006.

Little, Peter. 2005. Unofficial trade when states are weak: the case of cross-border Commerce in the Horn of Africa. Research Paper No. 2005/13. UN University-World Institute for Development Economics Research.(WIDER) and Expert Group on Development Issues (EGDI), Swedish Ministry of Foreign Affairs.

Longley, K and Wekesa, M. 2008. An Analysis of Kenya's Drought Responses: Lessons from the 2005-2006 Drought Response in Pastoral Areas (Draft Unpublished

McPeak, John, and Peter Little. 2003. Pastoral sedentarization and community resilience in response to drought: perspectives from Northern Kenya. Global Livestock Collaborative Support Project (GL-CRSP): Pastoral Risk Management Project, Research Brief 03-02-PARIMA May.

Muthee, A.M., and Kenya Livestock Sector Study. 2006. An analysis of pastoralist livestock products market value chains and potential external markets for live animals and meat. Deloitte Consulting Ltd. - Kenya. AU/IBAR: USAID/Kenya Northeast Pastoral Development Project (NEPDP).

Simpkin, Piers. 2004. Regional livestock study in the greater Horn of Africa. International Committee of the Red Cross (ICRC).

Ibid. Kenya Country Profile. ICRC.

Ibid. Ethiopia Country Profile. ICRC

Ibid. Somalia Country Profile. ICRC 
UN OCHA Pastoralist Communication Inititiative. The future of pastoralism in Ethiopia. UN OCHA Pastoralist Communication Inititiative, 2007

USAID/Ethiopia. 2006. Pastoral Livelihoods Program Summary

USAID/EA, 2007. Regional Enhanced Livelihoods for Pastoral Areas (RELPA) Programs; Enhanced Livelihoods in the Mandera Triangle (ELMT) Activity.

Wilson, T., G. Stockton, and P. Palmeri. 2004. Towards a Livestock Sector Strategy: Report No. 04/001 IC-SOM. FAO. European Union: World Bank.

doi:10.1186/2041-7136-2-6

Cite this article as: Stockton: Sugar for the tea: assistance and the State of pastoralism in the Horn of Africa. Pastoralism: Research, Policy and Practice 2012 2:6.

Submit your manuscript to a SpringerOpen ${ }^{\circ}$ journal and benefit from:

- Convenient online submission

- Rigorous peer review

- Immediate publication on acceptance

- Open access: articles freely available online

- High visibility within the field

- Retaining the copyright to your article

Submit your next manuscript at $\boldsymbol{\nabla}$ springeropen.com 